\title{
The Analysis of Jackson's Victory over the Second Bank of the United States
}

\author{
Weimin Liang \\ University of International Business and Economy, Beijing, China \\ Email: 1532599346@qq.com
}

How to cite this paper: Liang, W.M. (2018) The Analysis of Jackson's Victory over the Second Bank of the United States. Modern Economy, 9, 1121-1126. https://doi.org/10.4236/me.2018.96073

Received: April 28, 2018

Accepted: June 22, 2018

Published: June 25, 2018

Copyright $\odot 2018$ by author and Scientific Research Publishing Inc. This work is licensed under the Creative Commons Attribution International License (CC BY 4.0).

http://creativecommons.org/licenses/by/4.0/

\begin{abstract}
This article aims to analyze the reasons for the Jackson's bank war over the Second Bank of United States. It shows us a new perspective on the reason, which focuses on the different growth backgrounds of Jackson and Biddle. The President Jackson vetoed the bill for the postponement of the Second Bank of United States. And the different personality of Jackson and the Biddle, the president of the Second Bank of United States are important reasons for that. What's more, the collapse of the Second Bank of United States prevented the financial power from being too concentrated, which did harm to the state power. The Jackson's victory establishes the fundamental of Federal Reserve system, and gives the wall street spaces to flourish.
\end{abstract}

\section{Keywords}

President Jackson, Biddle, The Second Bank of United States, Growth Experiences, States Power, Federal Reserve System

\section{Background}

Before the establishment of the Second Bank of the United States, the First Bank of the United States declared disbanded after the expiration of 1811. State Banks grown fast and issued bank notes respectively. But many State Banks lacked enough reserve and the bank notes they issued were worthless, which led to malignant inflation and financial chaos. Besides, in March 1811, the Congress declared war on Britain. This war had greatly increased the cost of the US. The reference [1] shows that government bonds increased from $\$ 8$ million to $\$ 16$ million from 1811 to 1814 . The need to raise funds to support the war, had become a top priority, so it was urgent to set a national bank to support the financial operation and government credit.

Under these circumstances, in April 1816, the Congress passed the National 
Second Bank Act and the Second Bank of the United States was set up, whose charter was valid for 20 years. Compared with the First Bank of the United States, the capital of the Second Bank increased to 35 million dollars. The American Government owned one fifth of its stock, while the British owned one forth. As a central bank, the bank managed the government's reserve expenses, supervised the state bank's cash business, and mediated credit and currency circulation. But it was also a commercial bank that was privately owned and conducted business activities for the benefit of its shareholders.

So we need pay attention to the special environment when the Second Bank was founded: the United States was under the external threat of war and domestic trouble. The Second Bank of the United States was a product of centralization in an emergency period, so it inevitably damaged state power. Like the First Bank, the existence of the Second Bank was highly controversial, and people even wondered whether it was constitutional.

The article is organized as follows: the first part is the background of the bank war, which describes the financial conditions before the bank war. The second part is the introduction to the leaders of the bank war, Biddle and Jackson. The third part shows the main reasons for Jackson's Bank War. The forth and fifth part show the pros and cons of the bank war. The sixth part gives a conclusion and summary to this article.

\section{Introduction to Biddle and Jackson}

In order to discuss President Jackson's war against the Second Bank, we had to introduce the two major opponents of the bank war, Biddle and Andrew Jackson. Biddle was born in a wealthy home in Philadelphia, who was a child prodigy. He was admitted to the University of Pennsylvania at the age of 10. After completing all courses, the school refused to grant him a bachelor degree because he was too young, later he transferred to Princeton University and graduated at the age of 15 . So it's not hard to understand that he was a big, grumpy and extremely confident person. As the importance of the second bank increased, he felt that he was in power and could act arbitrarily and even despise the government. Biddle frequently used the economic power to influence the political process. In order to seek political help for the banks, he even used illegal means to bribe politician.

Different from Biddle's growth experience, President Andrew Jackson was born in the poor in 1767. Before he was born, his father died. At the age of 14, his mother also passed away. Young Jackson lives in poverty and was often bullied, his sympathy for the oppressed people originated from the experience and misfortune of childhood. What's more, Jackson was victimized by a promissory note during his youth, which incurs his hostile of bank.

The different growth experiences of Jackson and Biddle made them represent the interests of different classes, Bidlle's Second Bank of the United States represented the interests of the rich and foreigners in the eastern states but 
damaged the interests of the vast majority of small merchants and farmers in western and southern states, who were the main supporters of President Jackson. Thus President Jackson vetoed the bill for the postponement of the Second Bank of United States, although this bill has already been passed by the Congress. In 1836, the bank stopped its activities as a national bank.

\section{Reasons for Jackson's Bank War}

At the time, pioneers in the western States (including farmers and businessmen) were carrying out arduous pioneering operations, such as buying land and digging for gold. These activities needed the support of bank credit urgently, but the shareholder of the Second Bank were a few financiers and big businessmen in east states, the Second Bank used its monopoly to crowd out State Banks and loaned at a high interest rates. In order to purchase land, western residents had to borrow from the Second Bank at high interest rate. In western and southern states, people hated the Second Bank of the United States and hated the East.

Secondly, Biddle intervened in politics, bribed political leaders, intervening in presidential elections. When Jackson runs for President for the first time, he won most votes but failed to be the President because of Banker's transactions behind the scenes, this made him very annoying to the bank. Therefore, President Jackson vowed to kill the Second Bank of the United States.

\section{Pros of the Jackson's Victory}

\subsection{Help the Poor Get More Fair Services from the Bank}

The reference [2] notes that the closure of the Second Bank made the State Bank grown fast and common people was easier to get loans, which promotes the development of liberal capitalism. At the time, pioneers (including farmers, gardeners and businessmen) were keening to speculate on lands, which needed the support of bank credit urgently. The closure of the Second Bank removed the restraint on State Banks and made it easier for merchants and farmers to get loans from State Banks.

\subsection{To Prevent Financial Power Too Concentrated}

Jackson believed that the establishment of the Second Bank and issuing notes would lead the city to the countryside's exploitation and fraud, once the bankruptcy, the nearest city would be easier accessed to hedge gold and silver currency, while leaving the farmers a pile of paper. Therefore, the establishment of the bank could only make a group of swindlers to get rich, and sacrificed the interests of honest and hard-working people.

Second Bank was the monopoly rights granted to a small number of people who would oppose the principle of democracy, so the government of the country will be dangerous. As mentioned above, the president of the Second Bank, Biddle had huge power to reflect the American economy. He even intervened in presidential elections for their own interest. 


\subsection{Reflect of the American Democratic Ideology}

In Jackson era, the United States was in the transformation from agricultural society to industrial society. Both the coin and the soft currency belong to the disadvantaged group in the social transition period. The primary concern was their own position in the adjustment of social interests and their proportion of the total social wealth. The closure of the Second Bank gave disadvantaged group more opportunity to get loans and became wealthy.

\subsection{Make U.S. Financial System Free from the Control of British}

Among the shareholders of Second National Bank, Britons held 25\% of bank capital. These foreigners actually had the power to control the U.S. money supply. Once war happened, the consequences might be disastrous. Therefore, the closure of the Second Bank of United States prevented foreign financial intervention.

\section{Cons of the Jackson's Victory}

\subsection{Cause the Negative Effects on the American Economy in Short Term}

With the publication of the order, the government seems to be moving away from the state banks that no longer can be effectively controlled. The reference [1] pointed out that circulation order and the scattered Treasury caused the whole national economy to be in a state of chaos. At the same time, the deterioration of economic relationships between England and the United States also led to chaos in the foreign exchange market. At that time, England was the world's major financial and industrial power, it saw the United States as the main market for goods and capital in England, but also the main exporter of cotton in the United Kingdom. In order to raise gold reserves, the Bank of England raise interest rates to avoid the outflow of gold, which led to the decline in the volume of cotton imports in the United Kingdom, further affecting the U.S. economy.

\subsection{Cause the Financial Chaos and Crisis in 1830s}

The reference [3] notes that management mechanism is not to build a unified, centralized, the central bank, resulting in the entire banking system, the lack of a "lender of last resort", the National Bank reserves are too scattered, lack of coordination and cooperation between each other is necessary. Government bonds as collateral bank note issuance system and limit the money supply elasticity, etc. In the event of an emergency, such as the public squeeze on the run, the national bank is likely to occur due to a shortage of cash to stop payment, or even collapse. So it finally led to an unprecedented financial panic and depression in 1837.

\subsection{It Becomes Difficult for Government to Collect the Taxes and Fiscal Expenditure}

In fact, a federal bank as the core banking system to improve government 
finance, promote stable and sustainable economic development is very effective, is also consistent with the overall interests of the society, it should be said that everyone is a sound and stable banking system beneficiaries. The Second Bank effectively manage money, maintain bank credit, regulate transactions, protect the investment market, and continue to serve as Treasury agents.

\section{The Influence to the Modern Bank System}

\subsection{The American Government Is Aware of the Importance of the Central Bank}

As the national bank system was the product of political compromise, the technical level was lack of rigor and scientific. Especially the centralized management mechanism which does not have a unified, reserves are too scattered, lack of coordination and cooperation between all necessary national bank, government bonds as bank guarantee issued limited money supply elasticity. In addition, the national banking system also broke the Treasury's "independence", the Ministry of finance to the government for the sale of gold through changes in government bonds and bank deposits, and to influence national bank reserves, the central bank to assume the basic functions. However, the fluctuation and randomness of government revenue and expenditure will only aggravate the fluctuation of money market.

\subsection{Affect the Bank Legislation}

From the establishment of the national banking system for nearly half a century, the United States was in economic crisis and financial panic for almost every ten years. Although the malpractice of the national banking system is not the only cause, it is at least an important inducement. Moreover, the institutional arrangements of the national banking system can not only help to alleviate the crisis and panic, but the economic fluctuations and the instability of the monetary and banking system. Therefore, the United States began to make a banking reform movement from the bottom up. In view of the disadvantages of the national banking system, a protracted debate has been carried out, and a number of reform proposals have been put forward. Finally, the Wilson government because of the trend of the banking reform movement, the essence of the public program, taking into account the interests of all parties, established the Federal Reserve act. The establishment of the Federal Reserve System marked the end of the national banking system. In order to avoid the Democratic Party split, Jackson's designated successor Van Buren decided to implement the independent treasury system, namely the Ministry of Finance Treasury management direct federal government fiscal revenue, no longer in state banks, gold and silver was the only media of government revenue, refused to accept the bank notes as a means of payment. So it seems can meet the requirements of democratic factions: the government and the state bank cut off contact, means no government support for private interests, the end of improper influence banks and private 
banks on the privileged position of public policy, but also part of the gold and silver coins sent to wish the other means of circulation; on the one hand, means that the soft money sent from out of control of the federal government. Bad currency, counterfeit money flooded the field of circulation, ordinary people simply cannot be identified, so that the identification of the authenticity of the currency has become a good or bad.

\section{Conclusion}

In short, establishing and improving the stability of banking system, protecting the interests of the disadvantaged groups, the thought that populist ideology is giving priority to efficiency and fairness, constitutes the monetary history of the eternal conflict between them. Mutual influence and mutual restraint promote the reform and development of banking system, thus forming a different central bank system from the western countries, Federal Reserve System. The leaders of the bank war, Biddle and Jackson, are the representatives of different classes in the United States, their different personality is also the reflect of the interest of different classes.

\section{References}

[1] Peter, L. (2000) Rousseau. Jacksonian Monetary Polices, Species Flows, and the Panic of 1837. National Bureau of Economic Research, Cambridge.

[2] Temin, P. (1968) The Economic Consequences of the Bank War. Journal of Political Economy, 76, 257. https://doi.org/10.1086/259398

[3] Wallis, J.J. (2001) What Caused the Crisis of 1839? National Bureau of Economic Research, Cambridge. https://doi.org/10.3386/h0133 